\title{
オーステナイト系ステンレス鋼の孔食における 食孔成長についで
}

Tuguyasu Yoshii and Yoshihiro Hisamatsu : Pit Growth in Pitting Corrosion of Austenitic Stainless Steels. Growth of a single pit developed on austenitic SUS 27 (type 304) and SUS 28

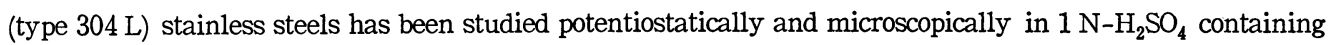
$0.5 \mathrm{~N}-\mathrm{NaCl}$ at $25^{\circ} \mathrm{C}$. The single pit was developed in the specimen surface of $0.95 \mathrm{~cm}^{2}$ by using, for example, a SUS 27 specimen pretreated in $1 \mathrm{~N}-\mathrm{H}_{2} \mathrm{SO}_{4}$ at $1200 \mathrm{mV}(\mathrm{SCE})$ and treated for repassivating film-breakthrough sites at $250 \mathrm{mV}$ in the solution containing chloride.

The critical potential for pitting is $400 \mathrm{mV}$ for SUS 27 and $250 \mathrm{mV}$ for SUS 28 , respectively. This is the boundary potential between the repassivation and pit-growth regions.

A distribution hystogram of diameters of film-breakthrough sites occurring in the repassivation region is given. A peak lies at $30 \sim 40 \mu$.

Concernning pit growth, the potential dependence of growth rate was determined. The current density per mouth area of the single pit is $0.3 \mathrm{~A} / \mathrm{cm}^{2}$ for both steels at the critical potential. The pit grown near the critical potential has a thick lid (Deckel) over its mouth.

The critical potential for pitting seems to be a minimum potential which allows the flow of current enough to concentrate chloride in the pit to a critical value. The lid would be convenient to maintain the high chloride concentration.

(Received November 7, 1970)

\section{I. 緒言}

前報(1)では孔食を食孔発生の面から眺め, 食孔発生に及 ぼす表面皮膜の影響を報告した，本報では発生後の挙動に ついて報告する.

食孔の成長に関する従来の研究には, Engell ら ${ }^{(2) \sim(5)}$ に よる鉄の研究がある. 孔食電流が食孔数と食孔成長速度と の関数として表わされることを示し，また食孔径増加の顕 微鏡による直接観察や孔食電流を全食孔口面積で割ること に上り食孔の電流密度を求めている。 これによると食孔の 成長速度は $\mathrm{Cl}^{-}$イオン濃度に依存するが，電位には依存せ ず，また食孔内の溶解挙動が活性態に打ける溶解挙動と 類似することが示されている１8-8ステンレス鋼では Schwenk ${ }^{(6)}$ が, $16 \mathrm{Cr}$ - $\mathrm{Fe}$ 合金では Smialowska と Czachor ${ }^{(7)}$ が食孔内表面積を求めることによって, Al では Kaesche(8) が孔食電流の解析より, 食孔内の真電流密度を求めてい る. 鈴木ら ${ }^{(9) \sim(11)}$ は人工ピットを用いて食孔内の分極曲線 を取っている. 食孔内では電流の流れにともなら濃度の変 化が起こる. Kaesche(8)はA1 について移動モデルを適用し

** 東京大学工学部冶金学科 (Department of Metallurgy, Faculty of Engineering, University of Tokyo, Tokyo)

* 1970 年 10 月第 17 回腐食防食討論会に発表

（1）久松, 吉井：金属学会誌, 34 (1970), 1207.

(2) H.-J.Engell und N.D.Stolica : Z.phys. Chem. N. F., 20 (1959) , 113.

(3) H.-J.Engell und N. D. Stolica : Arch. Eisenhütt., 30 (1959) , 239.

(4) G.Herbsleb und H.-J.Engell : Z.phys. Chem., 215 (1960), 167.
て食孔内の各種イオン濃度を推定し，孔食電流と bulk $\mathrm{Cl}^{-}$ イオン濃度との関係を求めた.

これらの研究の基礎となっている孔食電流の解析は, 表 面に多数の食孔が発生するため, 平均的取扱いしかできて いない，我々は前報で食孔の発生挙動を調べ，発生する食 孔の数を control できることを知った。 これを応用して， 試片面に単一の食孔が発生するよ5に工夫して, 食孔成長 挙動を調べたのでその結果を報告する。

\section{II. 実 験 方 法}

\section{1. 試片の作製}

オーステナイト系ステンレス鋼 SUS 27 とUS 28 を用 いた．組成および試片調製法は前報の通りである。

\section{2. 定電位法による再不働態域の観察 (実験 1)}

試片を前報と同じアクリル製電解槽に装着する. テフロ ンガスケットによって試片面は $0.95 \mathrm{~cm}^{2}$ 露出している. $200 \mathrm{~mL}$ の $1 \mathrm{~N} \mathrm{H}_{2} \mathrm{SO}_{4}$ 中 $25 \pm 0.5^{\circ} \mathrm{C}$ (以下全て $25^{\circ} \mathrm{C}$ 恒温) で, 空気乾燥中にでさた酸化皮膜を除去するために，まず $-600 \mathrm{mV}$ vs. SCE (以下全て SCE 基準) で $5 \mathrm{~min}$ 間カソー

(5) G.Herbsleb und H.-J.Engell : Z. Elektrochem., 65 (1961) , 881.

(6) W. Schwenk : Corrosion, 20 (1964), 129 t.

(7) Z.Szklarska-Smialowska and M. Janik-Czachor : British Corr.J., 4 (1969) , 138.

(8) H.Kaesche : Z.Phys.Chem.N.F., 34 (1962) , 87.

（9）鈴木，北村：防食技術, 17 (1968)，535.

(10) 鈴木，北村：防食技術, 18(1969)，100.

(11) 鈴木, 北村 : 電化, 38(1970), 562 . 
ド還元後, $1200 \mathrm{mV}$ の過不働態に液を $\mathrm{N}_{2}$ で攪找しなが ら $15 \mathrm{~min}$ 保持し, 過不働態皮膜を生成させた。終了後 $1 \mathrm{~N} \mathrm{H}_{2} \mathrm{SO}_{4}$ で洗い，脱気 $1 \mathrm{~N} \mathrm{H}_{2} \mathrm{SO}_{4} 150 \mathrm{~mL}$ を入れ所定の電 位に設定する。 $1 \mathrm{~N} \mathrm{H}_{2} \mathrm{SO}_{4}+1 \mathrm{~N} \mathrm{NaCl} 150 \mathrm{~mL}$ を $\mathrm{N}_{2}$ で液を 強く䚓拌しながら 2 min で加兄, $1 \mathrm{~N} \mathrm{H}_{2} \mathrm{SO}_{4}+0.5 \mathrm{~N} \mathrm{NaCl}$ に する.さらに $2 \mathrm{~min}$ 攪拌を続けた後，攪拌を停止して電流 変化をみる.

\section{3. 成長域において，孔食電流が $200 \mu \mathrm{A}$ に達する までの時間と, 食孔口面積当りの電流密度の 測定 (実験 2)}

実験 1 の手順と同じであるが，皮膜作成はSUS 28 では $1200 \mathrm{mV}$ の過不働態で, SUS 27 では $1200 \mathrm{mV}$ の過不働 態と 300 および $900 \mathrm{mV}$ の不働態で行なった。

試片面に単一の食孔を発生・成長させるテクニックとし ては，前報で述べたごとく，食孔の発生を少なくするょう 飞, 不働態皮膜を有する試片を使えばよい. しかし SUS 28 の場合誘導時間が長くて実験が困難なので, 過不働態皮膜 を有するあのを使ったが, SUS 27 に較べ食孔の発生が少 ないので, 後述の操作で単一食孔を成長させ得る.比較のた めSUS 27 で過不働態皮膜のるのを使 5 時は, あらかじめ 破壊を受けやすい所を再不働態化した後所定の電位におい た。操作法は次の通りである. SUS 27 の不働態皮膜を有す るもの拉よび SUS 28 では, $100 \mathrm{mV}$ で溶液 混合後所定の 電位に保持し, 最初の $5 \mathrm{~min}$ 以内に発生した食孔は, 孔食 電流が $10 \mu \mathrm{A}$ 飞達する前に電位を $100 \mathrm{mV} \cdot$ に下げて強制 的に再不働態化させ，再び電位を所定の所に戻して新たに 別の食孔を発生させた. SUS 27 の過不働態皮膜のものは， $100 \mathrm{mV}$ で溶液混合後 $250 \mathrm{mV}$ の再不働態域に 20 30 min 保持し，再不働態域での皮膜破壊部が完全に再不働態化し たのをみて所定の電位に上昇させた. このようにしたのち 計測される孔食電流は, ほとんどの場合 1 個の食孔に対応 していた.

孔食電流が $200 \mu \mathrm{A}$ になるまで保った後, 取り出して食 孔径を測り, 食孔口面積当りの電流密度を求め, 同時に電 流增加がみられた時点から $200 \mu \mathrm{A}$ になるまでの時間を測 定した．食孔口は注湆円形であるので長径と短径を測り平 均し，円として面積を算出した。

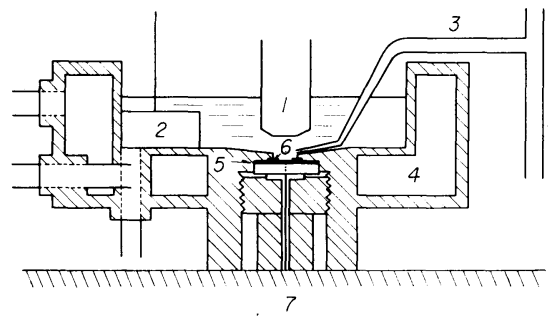

1. objective lense ; 2 . Pt counter electrode

3 . capillary; 4 . water jacket; 5 . specimen 6. teflon gasket; 7. microscope stage

Fig.1 Cell for observation of pit growth

\section{4. 食孔形態の直接観察（実験 3)}

試料は SUS 27 である. 顕微鏡下の観察に適するように 作ったアクリル製電解槽 Fig.1 を用いた. 試片面はテフロ ンガスケットによって約 $0.4 \mathrm{~cm}^{2}$ 露出するようになってい る. 対物レンズは高温顕微鏡用の長焦点レンズを用い, レ ンズ以外を防食被覆し溶液に浸漬した。 $1 \mathrm{~N} \mathrm{H}_{2} \mathrm{SO}_{4}$ 中で過 不働態皮膜処理ののち, 液を $1 \mathrm{~N} \mathrm{H}_{2} \mathrm{SO}_{4}+0.5 \mathrm{~N} \mathrm{NaCl}$ にか え, 所定の電位に保って食孔形態を写真撮影した。

\section{III. 実 験 結 果}

\section{1. 定電位法による再不働態域の観察 (実験 1 の結果)}

Fig. 2 に実験 1 の結果すなわち SUS 27 の電流の時間変 化を示す．この場合，皮膜破壊個所は数力所ある. 200〜 $350 \mathrm{mV}$ は前報のステップ法でもみた通り，この合金に対 しては再不働態域で, 破壊部は複雑な電流変化挙動を示し たのち再不働態化する(すなわち破壊電流は消隇する)。 SUS 28 ではこの電位域で食孔成長を示し, 再不働態域は $200 \mathrm{mV}$ 以下になる. SUS 27 の皮膜破壊部は前報 (Photo. 1 (a)) に示した通り開口型である. Photo.1 に成長と再不 働態化の境界領域にできた食孔の形態を示す. SUS 28 の

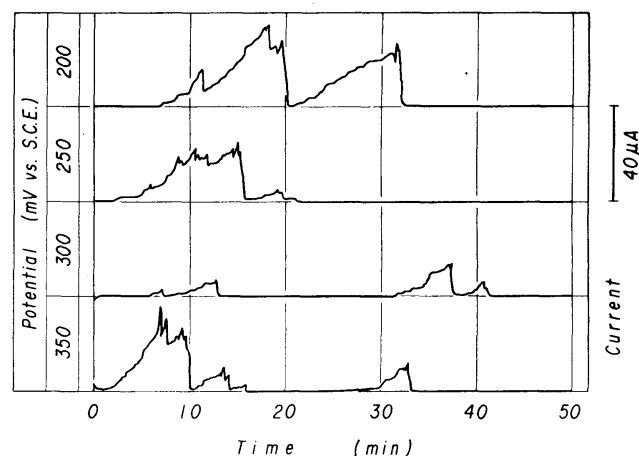

Fig.2 Current-time curves of SUS 27 (type 304) steel measured by the potentiostatic method in $1 \mathrm{~N}-\mathrm{H}_{2} \mathrm{SO}_{4}$ containing $0.5 \mathrm{~N}-\mathrm{NaCl}$ at $25^{\circ} \mathrm{C}$. The curves show that film-breakthrough and repassivation occurred at these potentials less noble than the critical potential

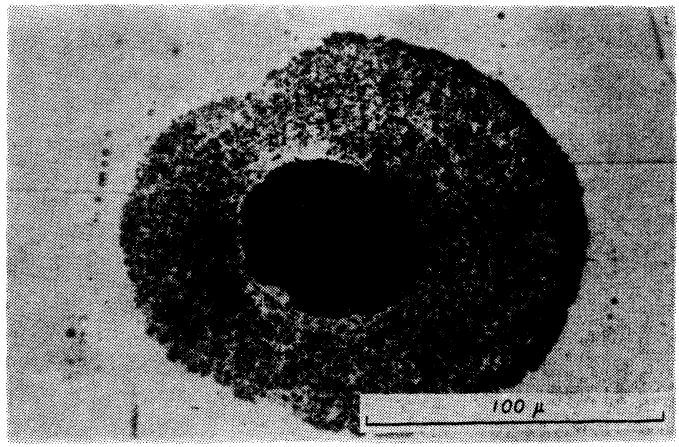

Photo.1 Pit developed at the boundary potential between the repassivation and pit-growth regions. SUS 27 steel in $1 \mathrm{~N}-\mathrm{H}_{2} \mathrm{SO}_{4}$ containing $0.5 \mathrm{~N}-\mathrm{NaCl}$ 
$200 \mathrm{mV}$ に和ける皮膜破壊部の形態はPhoto.1 飞近いもの であった. Fig.3 にSUS 27 の $250 \mathrm{mV}$ で再不働態化した 破壞部の長径の分布を示す. 30 40 $\mu$ の所にピークがあ る.

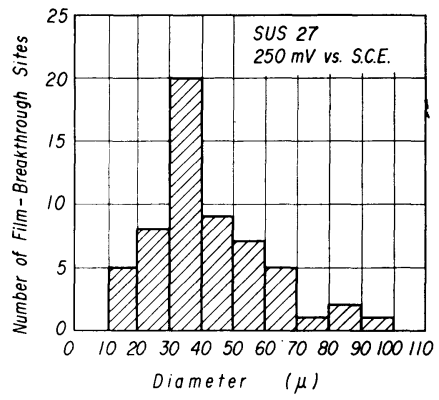

Fig.3 Distribution hystogram of major diameters of film-breakthrough sites in the repassivation region

\section{2. 食孔成長域における挙動 (実験 2 の結果)}

Fig. 4 飞 SUS 27 の $400 \mathrm{mV}$ と $500 \mathrm{mV}$ での単一食孔か らの孔食電流の時間変化を示した．Fig.5 亿単一食孔の孔 食電流が $200 \mu \mathrm{A}$ に達するまでの時間を, Fig.6 亿食孔口 面積当りの電流密度を，それぞれ保持電位に対してプロッ トしたものを示す. SUS 27 とついて行なった皮膜処理に 怙ける不働態・過不働態皮膜処理の差は有意に現われなか ったＦig.5, 6 とも平均値と Range を示している．Fig.5 にみるよ5に孔食電位近傍ではバラッキが大きく, $400 \mathrm{mV}$ 以上では $200 \mu \mathrm{A}$ 達する時間が急速に短くなってゆき， これに対応して Fig.6でみるよ5に，電流密度は電位依存 性を有して高い電位ほど電流密度が高くなってゆく．SUS 27 の再不働態域に対応している 200〜350 mV では, SUS 28 の食孔成長には電位依存性がない. $450 \mathrm{mV}$ 以上では SUS 27 と SUS 28 の挙動が同一である.

実験後取り出して顕微鏡観察すると，前報 Photo. 2 で示 したような‘ふた’の存在がみられた。‘ふだは皮膜をその

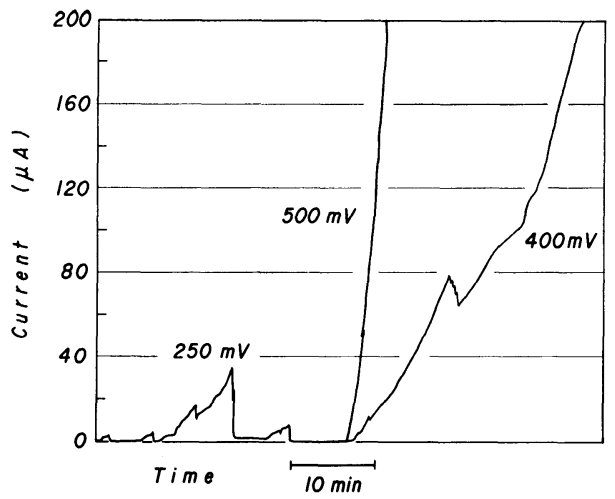

Fig.4 Variation in pitting current with time for the single pit developed at the potentials more noble than the critical potential after repassivation treatment at $250 \mathrm{mV}$. SUS 27 steel in $1 \mathrm{~N}-\mathrm{H}_{2} \mathrm{SO}_{4}$ containing $0.5 \mathrm{~N}-\mathrm{NaCl}$ at $25^{\circ} \mathrm{C}$

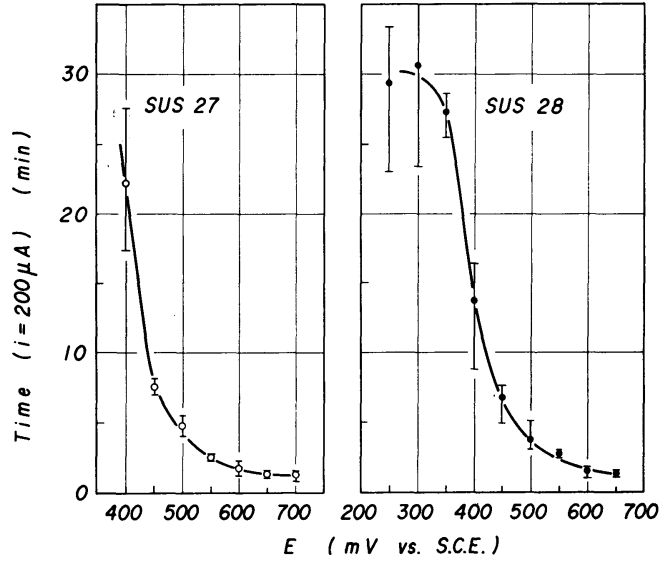

Fig.5 Potential dependence of the time at which the pitting current of the single pit reaches $200 \mu \mathrm{A}$
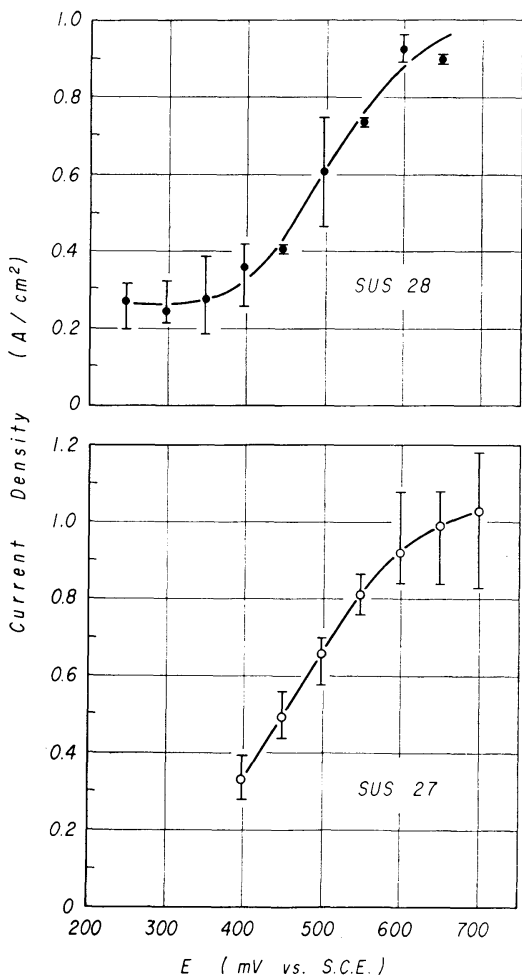

Fig.6 Potential dependence of current density per mouth area of the single pit

下の金属が溶け残って支兑ているかたちで，‘ふた’の全面 に細孔が多数分布していた，低電位域(食孔成長域内で)で できたものは中央に小孔が開いている場合が多く，‘た” は丈夫で水洗しても食孔内に落ち込んで残ることがあっ た，高い電位域では薄くて弱く，水洗によって取れる.

\section{3. 食孔形態の直接観察 (実験 3 の結果)}

Photo. 2 に実験 3 の結果の一例を示す．写真は $450 \mathrm{mV}$ の場合で, 最後の 9 番目を除いて $15 \mathrm{sec}$ おきに撮影してい 
る、食孔は上に“ふた”をから゙って特り、“らた’にるとの表 面の粒界が残っているのがみえる，成長は必ず “らた”の 下で進行する，高い電位での成長では，試片表面に拉ける 食孔の形は添济円形で，徍は時間に比例して增大する，低 い電位では途中形くずれを起こすのがみられた。

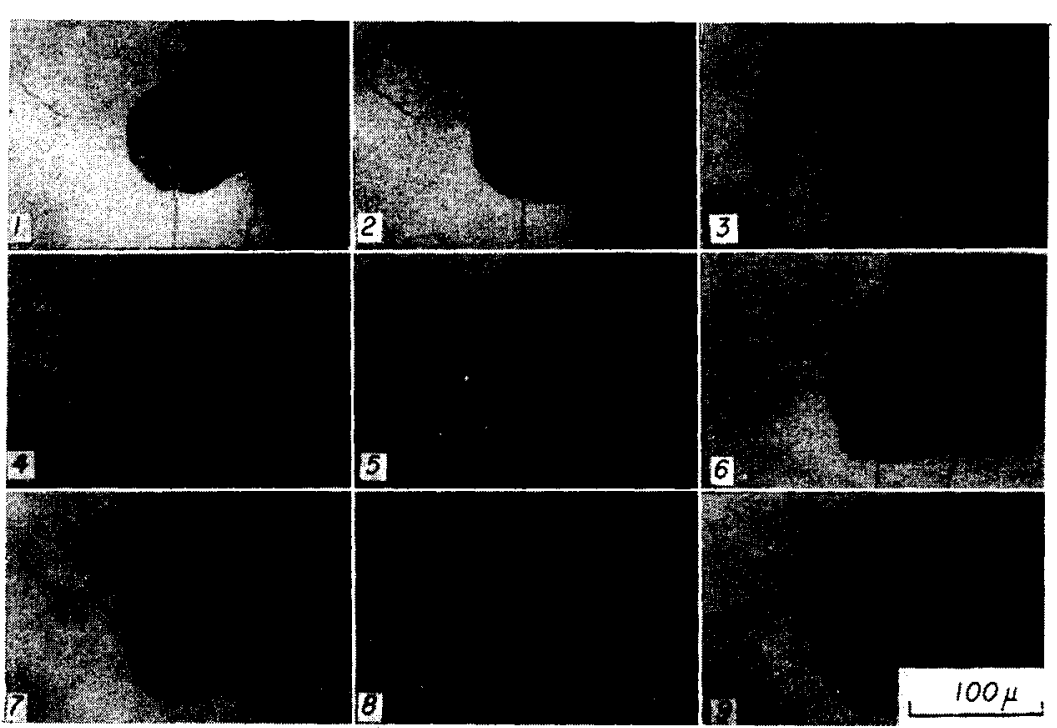

Photo.2 Pit grown on SUS 27 (type 304 ) steel at $450 \mathrm{mV}$ in $1 \mathrm{~N}-\mathrm{H}_{2} \mathrm{SO}_{4}$ containing $0.5 \mathrm{~N}-\mathrm{NaCl}$. Interval of each micrograph is $15 \mathrm{sec}$ except No.9

\section{IV. 考察}

定電位保持の場合，食孔の成長は孔食電流の増加によっ て示される，我々性成長とい5基準を，単一食孔の孔食電 流が $200 \mu \mathrm{A}$ に達し得るということに打いた。

前報で述べたよ 5 に, $25^{\circ} \mathrm{C} 1 \mathrm{~N} \mathrm{H}_{2} \mathrm{SO}_{4}+0.5 \mathrm{~N} \mathrm{NaCl}$ 中で はわれわれが使用したステンレス鋼の举動は電位によっ て, 電位の低い方から不㗢態域, 再不動態域, 食孔成長域 と続いて変わる，再不働態域と成長域との境が孔食電位で あるが，われわれの場合これはあまり明確なるのではなか った，孔食電位はSUS 27 で $400 \mathrm{mV}$, SUS 28 で $250 \mathrm{mV}$ 付近である，孔食電位以下の再不㗢態域では，破壊部は Fig.2 に示すような電流変化によって，ある程度広がった 後再不㗢態化してしまう，孔食電位以上の電位で食孔が成 長する場合, Fig.4の $400 \mathrm{mV}$ の曲線が示す上 5 に, 孔食 電位近傍では孔食電流の時間的変化は単調でない，食孔成 長の直接観察の際も途中成長の停滞, 形くずれがみられた (Photo.2).これがFig.5で低い電位でバラッキが大きくな るのに対応している，電位が高くなると Fig.4の $500 \mathrm{mV}$ の場合にみるように孔食電流も単調に増加するようにな り，形態む食孔径が時間に比例して增大するようになって 成長が安定してくる，Fig.6 で SUS 27，SUS 28 とも成長 をみる $400 \mathrm{mV}$ 以上の電位で, 電流密度が電位依存性を有 している。電位依存性については Schwenk ${ }^{(6)}$ が 18-8 ステ ンレス鋼について，1M NaCl 中で食孔数と孔食電流が 300
$\mathrm{mA}$ に達するまでの時間との関係にすとついて, $16 \mathrm{Cr}$ Fe 合金については Smialowska $5^{(7)}$ か $0.7 \mathrm{~N} \mathrm{Na}_{2} \mathrm{SO}_{4}+$ $0.7 \mathrm{~N} \mathrm{NaCl}$ 中で食孔内電流密度の湘定より示している. これらの実験では食孔数が多く，平均的な取扱いである. 単一食孔を成長さすことによって電位依存性がより明確に つかめた. 見かけの Tafel 係数 は 400〜 $500 \mathrm{mV}$ で約 $0.39 \mathrm{~V} /$ decade であり，大きな分極作用 が予想されるが，電位が高くな るとこの值はさらに大きくな る. $450 \mathrm{mV}$ 以上の電位では SUS 27 , SUS 28 とも同じ電流 密度を取っている。これはSUS 27, SUS 28 と安定成長が保証 される電位域では食孔の成長に 差が生じないことを示してい る.

SUS 27 とUS 28 の差は 400 $\mathrm{mV}$ 以下で非常に顕著になって くる. SUS 27 では再不働態域 が $350 \mathrm{mV}$ をで, SUS 28 では $200 \mathrm{mV}$ まででこの間に 150 $\mathrm{mV}$ のひらきが生ずる。また， この間の電位ではSUS 28 の食孔口面積当りの電流密度は 電位依存性がない：この電位域で SUS 27 の皮膜破填部が 前報の Photo.1 (a) に示したよ5な開口型であるのに対し て, SUS 28 の場合には ‘ぶをかぶった成長性食孔であ る。実際の腐食条件では，食孔は孔食電位近傍で起こるこ とが多く、この種の ‘ふた’付の形態が問題になるである 5. 実験的には Rosenfel’d ${ }^{(12)(13)}$ らは酸化剂を含む塩化物 中で，間隙の原因をつくる ‘ふた'の存在を重視している. Engellら ${ }^{(14)}$ に上っても中性塩化物溶液中のステンレス鋼で ‘ふた’の存在が確認されている. 問題の ‘ふた’がどうし て SUS 28 の方が生じやすいのかは不明である、本実験で は両合金の美が高い電位では現われず，孔食電位近傍のと ころに出ている。

$1 \mathrm{~N} \mathrm{H}_{2} \mathrm{SO}_{4}+0.5 \mathrm{~N} \mathrm{NaCl}$ 中の活性域の分極挙動を較べた 限りでは両合金に差がなかった。

SUS 27 の $400 \mathrm{mV}$ での食孔口面積当りの電流密度を食 孔径比してプロットしたものが Fig.7である、口径が 小さいもの汪ど口面積当りの電流密度が大きい，再不動態 化直前のピーク電流を破壊部口面積で割って，再不動態皮 膜破壊部の電流密度を，破壊個䄼の少ない試片について求

(12) I.L.Rosenfel'd und I. S. Danilow : Z.Phys. Chem., $226(1964), 257$.

(13) I. L. Rosenfel'd und I. S. Danilow : Corr. Sci., 7 (1967) , 129.

(14) P.Forchhammer und H.-J.Engell : Werk.u.Korr., 20 (1969), 1. 
めてみると, SUS 27 の $250 \mathrm{mV}$ では $0.38 \mathrm{~A} / \mathrm{cm}^{2}, 150 \mathrm{mV}$ では $0.41 \mathrm{~A} / \mathrm{cm}^{2}$ であり, SUS 28 の $200 \mathrm{mV}$ では $0.32 \mathrm{~A} /$ $\mathrm{cm}^{2}$ であった。再不働態域に打ける皮膜破壊部は小さいの で多少高く求められているが, 孔食電位での值にほぼ等し い.

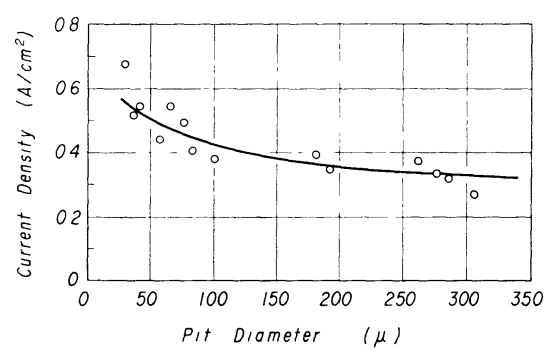

Fig.7 Change in the current density per mouth area of the single pit with pit diameter. SUS 27 steel at $400 \mathrm{mV}$ in $1 \mathrm{~N}_{-} \mathrm{H}_{2} \mathrm{SO}_{4}$ containing $0.5 \mathrm{~N}-\mathrm{NaCl}$

Fig. 3 に示された再不働態域皮膜破壊部の長径の值は, 孔食を核生成・成長過程とみるときの臨界径に相当するる のが，この場合かなり大きな值であることを示していると 解积される.

Fig.6 にみるよ5に食孔として成長するに必要な電流密 度はこの場合 $0.3 \mathrm{~A} / \mathrm{cm}^{2}$ と, 18-8 ステンレス鋼のアノー ド溶解電流としてはかなりの值になっているが, 他の研究 者によって求められた值も, 孔食電位近傍では Table 1 亿 示すよらに大きな值である. いずれる半球形食孔内の真電 流密度という形で表示されているので， 2 倍して食孔口面 積当りの電流密度にな扎してある。 これらの電流密度は食 孔内 $\mathrm{Cl}^{-}$イオン濃度をある濃度(物そらく金属塩化物の飽 和濃度) に保つょうに働いている. 食孔内の $\mathrm{Cl}^{-}$イオン濃 縮に関するものとしては, Kaesche(8) は A1 について移動 モデルを作って, 食孔内 $\mathrm{Cl}^{-}$イオン濃度を外部溶液濃度, 電流密度怙よび拡散層の厚み, 拡散係数の関数として出し, 濃度を見積っている. 鈴木 ${ }^{(10)}$ は人工ピットを使って中性 外部容液の $0.9 \mathrm{NCl}^{-}$飞対して食孔内は $2.7 \mathrm{~N}$ まで濃縮す

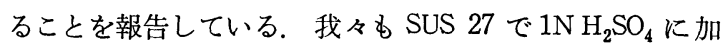
える $\mathrm{NaCl}$ 濃度を增してゆけば, 分極曲線の活性態のピー ク電流密度が大きくな $\left(1 \mathrm{~N} \mathrm{H}_{2} \mathrm{SO}_{4}+4 \mathrm{~N} \mathrm{NaCl}\right.$ で $60 \mathrm{~mA} /$ $\mathrm{cm}^{2}$ ) とをみて扣り, $\mathrm{Cl}^{-}$イオン濃縮は食孔成長の必須条 件である. Fig.7 にみるょ5に小さな食孔でも電流密度が 高いことょり, 濃縮は非常に速い速度で起こるし, 低電位 域での丈夫な ‘ふた’ は食孔内の $\mathrm{Cl}^{-}$イオン濃度に都合の よい条件を作っているものと考穴られる, 必要最小電流密 度に対応する電位が孔食電位と考えるのが妥当であるう が, $\mathrm{H}_{2} \mathrm{SO}_{4}+\mathrm{Cl}^{-}$溶液中のステンレス鋼の上うに, ‘ふた'が
物質移動に影響を及ぼすような場合には，孔食電位がごく せをい電位範囲に定まりにくいのであろう。

Table 1 Current density per mouth area of the pit grown at potentials near the critical potential for pitting

\begin{tabular}{|c|c|c|c|}
\hline Metal & Solution & $\begin{array}{l}\text { Current } \\
\text { density } \\
\left(\mathrm{A} / \mathrm{cm}^{2}\right)\end{array}$ & Ref. \\
\hline $\mathrm{Fe}$ & $\begin{array}{l}\begin{array}{l}1 \mathrm{~N} \mathrm{H}_{2} \mathrm{SO}_{4} \\
+ \\
4 \times 10^{-3} \mathrm{M}\left[\mathrm{C}^{-}\right]\end{array} 25^{\circ} \mathrm{C}\end{array}$ & $0.34 \times 2=0.68$ & (5) \\
\hline $\begin{array}{l}16 \mathrm{Cr}-\mathrm{Fe} \\
\text { alloy }\end{array}$ & $\mid \begin{array}{ll}0.7 \mathrm{~N} \mathrm{Na}_{2} \mathrm{SO}_{4} & \\
+ & \\
0.7 \mathrm{~N} \mathrm{NaCl} & 25^{\circ} \mathrm{C}\end{array}$ & $0.5 \times 2=1.0$ & (7) \\
\hline $\begin{array}{c}18 \mathrm{Cr}-10 \mathrm{Ni} \\
\text { stainless } \\
\text { steel }\end{array}$ & $\mid \begin{array}{l}1 \mathrm{~N} \mathrm{H}_{2} \mathrm{SO}_{4} \\
+\underset{+}{\mathrm{M} \mathrm{NaCl}}\end{array}$ & $0.5 \times 2=1.0$ & (6) \\
\hline $\begin{array}{l}\text { Austenitic } \\
\text { steinless } \\
\text { steel }\end{array}$ & $\begin{array}{l}0.04 \mathrm{M} \mathrm{FeNH}_{4}\left(\mathrm{SO}_{4}\right)_{2} \\
+ \\
0.56 \mathrm{M} \mathrm{NH}_{4} \mathrm{Cl}\end{array}$ & $0.12 \times 2=0.24$ & (13) \\
\hline $18-8\left(\begin{array}{l}304 \\
304 \mathrm{~L}\end{array}\right)$ & $\begin{array}{c}1 \mathrm{~N} \mathrm{H}_{2} \mathrm{SO}_{4} \\
+\stackrel{+}{ } \\
0.5 \mathrm{~N} \mathrm{NaCl}\end{array}$ & 0.3 & $\begin{array}{c}\text { Present } \\
\text { result }\end{array}$ \\
\hline
\end{tabular}

\section{V. 総括}

SUS 27 とUS 28 を用い, $25^{\circ} \mathrm{C}$ の $1 \mathrm{~N} \mathrm{H}_{2} \mathrm{SO}_{4}+0.5 \mathrm{~N} \mathrm{NaC}$ 中で単一の食孔を成長させ, 孔食電流が発生後 $200 \mu \mathrm{A}$ に 達するまでの時間, 食孔口面積当りの電流密度を求め, 食 孔の成長挙動を比較検討した。 この溶液中では電位の低い 方から不働態域, 再不働態域, 食孔の成長域と続いて変わ る. 成長が充分保証される高い電位域では, 成長は電位依 存性を有し電位が高くなるほど成長が速くなるが，両合金 で成長に差が認められなかった，両合金の差は低い電位域 に現われ，250〜350 mV (SCE) の間はSUS 27 の方が径が 30 40 $\mu$ で皮膜破壊部が再不働態化するのに, SUS 28 で は食孔成長が起こる. この差は形態上, 孔の上に‘ふた’が あるかないかの差であった. 食孔成長の直接観察からも, 成長する食孔には必ず ‘ふた’があり，成長は ‘ふた’ の下 で進行する. ‘ふた’ は電位が高くなると薄く弱くなる. 孔 食電位抢よび再不働態域の口面積当りの電流密度もほほ问 じ約 $0.3 \mathrm{~A} / \mathrm{cm}^{2}$ である. この大さな電流密度は, 食孔内 の $\mathrm{Cl}^{-}$イオン濃度をある基準に保持するために必要な最低 の電流であると考えられる. ‘ふた’ はこの濃縮に都合のよ い条件を作っているとみなされる.

終りに，ステンレス鋼試料につき执世話たまわった日新 製鋼周南工場 土居浩一部長に感謝する. 